ISSN 2411-4758 (Print) 2518-1602 (Online)

Native word in ethnocultural dimension, Drohobych, Posvit, 2021, pp. 159-168.

DOI: https://doi.org/10.24919/2411-4758.2021.217116

УДК 811.161.2’42:177.1]:821.161.2Bop1/7].09

\title{
ФОРМУЛИ ЕТИКЕТУ ЯК МАРКЕРИ МОВНОЇ КАРТИНИ СВІТУ БУКОВИНЦІВ У ХУДОЖНІХ ТЕКСТАХ С. ВОРОБКЕВИЧА
}

\section{Наталія ШАТІЛОВА,} кандидат філологічних наук, асистент кафедри сучасної украӥнської мови, Чернівецький національний університет імені Юрія Федьковича (Україна, Чернівиі) n.shatilova@chnu.edu.иа

ORCID: http://orcid.org/0000-0003-1233-1934

Research ID: D-2948-2017 http://www.researcherid.com/rid/D-2948-2017

Статтю подано до редколегіï / The article is submitted to the editorial board: 15.10.2020.

Статтю опубліковано / The article is published: 22.02.2021.

У статті описано змістові й функціональні параметри стереотипних культурно та етнічно зумовлених етикетних формул, уживаних у художніх текстах С. Воробкевича, щуо їх буковиниі уживають в типових комунікативних ситуаціях - привітання, прощуання, побажання, подяки, прохання, вибачення, гостинності, утішання. 3'ясовано, щзо випрацювані віками ввічливо-доброзичливі конструкції мовного спілкування репрезентують національний характер буковинців, їху. ментальність, самобутній спосіб мовомислення й світобачення.

Ключові слова: мовний етикет; мовленнєвий етикет; мовні формули етикету; комунікативна ситуація; національно-мовна картина світу.

\section{ETIQUETTE FORMULAS AS MARKERS OF BUKOVINIANS' LANGUAGE PICTURE OF THE WORLD IN THE ARTISTIC TEXTS OF S. VOROBKEVYCH}

\section{Nataliya SHATILOVA,}

Ph.D. in Philology, Senior lecturer, Department of Modern Ukrainian Language, Yuriy Fedkovych Chernivtsi National University (Ukraine, Chernivtsi)n.shatilova@chnu.edu.ua

The purpose of the article is to describe the semantic and functional parameters of stereotypical culturally and ethnically determined etiquette formulas that Bukovinians 
use in typical communicative situations. The study was conducted on the basis of artistic texts of the famous Bukovinian writer $S$. Vorobkevych.

Systematic use of etiquette constructions, the ability to reproduce in typical situations of interpersonal communication has predetermined to their stability, stereotyping, standardization, has given them the character of stable formulas, forming a number of semantic and functional varieties. The article identifies and describes the following typical etiquette situations of communication: greetings, farewells, wishes, thanks, requests, apologies, hospitality, consolation.

It was found that the literary texts of $S$. Vorobkevych represent the language etiquette of Bukovynians as an integral part of the Ukrainian ethnic group. The speeches of the characters of his works are filled with constructions of respectful communication of the inhabitants of Bukovina, based on local traditions, customs, rites and beliefs. The politely well-disposed constructions of language etiquette developed over the centuries, recorded in the writer's texts, illustrate the national character of the Bukovynians, their mentality, original way of thinking and worldview. Various types of traditional constructions have mostly desirable character and religious theme, contain colloquial, dialectal lexemes and phrases, demonstrate the paremic creativity of the Bukovinians. They not only express the language culture and picture of the world of the inhabitants of Bukovina, but also emphasize their ethnopsychological features such as friendliness, politeness, sensitivity, sincerity, respect, piety, religiosity, emotionality.

Further analysis of the selected writer's texts on the functioning of language etiquette units relevant to communicative situations of congratulations, courtship, blessing, approval, advice, kindness, consent or refusal etc. as identifiers of the mental worldview of Bukovina residents is perspective.

Keywords: language etiquette; speech etiquette; language formulas of etiquette; communicative situation; national-linguistic picture of the world.

Постановка проблеми. Самобутність кожного народу в контамінації з традиціями, культурою, етнопсихологічною специфікою, морально-етичними орієнтирами увиразнюють стереотипи мовної поведінки, що фокусують виформувані упродовж століть риси національної вдачі й характеру. Традиційні усталені вислови, зазвичай уживані в певних життєвих ситуаціях, маркують мовну картину світу українців, відображають специфіку їхнього національно-мовного світобачення. Як вербальні репрезентанти української етнокультури такі структури цікаві й в аспекті дослідження ідіостилю письменника, оскільки ідентифікують своєрідність менталітету автора, надаючи його художнім текстам національного й регіонального колориту.

Аналіз досліджень. Мовні стереотипи спілкування, національно специфічні узвичаєні формули, що їх застосовують під час безпосереднього контактування у вибраній тональності, не воднораз привертали увагу вітчизняних (Н. Бабич, А. Балакай, Ф. Бацевич, М. Білоус, С. Бог- 
дан, Н. Гуйванюк, С. Срмоленко, Т. Космеда, В. Литовченко, О. Мельничук, О. Миронюк, М. Пахоменко, О. Потебня, В. Сімович, М. Скаб, М. Стахів, М. Стельмахович, Я. Радевич-Винницький, С. Чак та ін.) та зарубіжних (П. Браун, П. Грайс, С. Левінсон, П. Лекант, Н. Формановська та ін.) дослідників. Вербальні етикетні вияви досліджують у художньому (Г. Бірюліна, О. Мельничук), фольклорному (О. Гриценко, Н. Данилюк), науковому (О. Ільченко), епістолярному (Н. Журавльова, Н. Плющ), дипломатичному (О. Мацько), суспільно-політичному (Л. Мудрик, О. Лукащук), мас-медійному (І. Пахомова) та інших типах дискурсу.

Різноаспектний дослідницький інтерес до системи стійких етикетних одиниць спілкування виформував низку термінів на їх позначення, як-от: «мовний етикет» (Богдан, 1998; Срмоленко, 2004; Миронюк, 1993; Плющ, 1991), «мовленнєвий етикет» (Стельмахович, 2001); «лінгвоетикет» (Радевич-Винницький, 2008), «комунікативний етикет» (Стахів, 2008), «етикетні формули» (Богдан, 1998), «етикетні висловлення» (Гуйванюк, 1995), «етикетні комунікеми (етикетні мовні стереотипи)» (Пилипко, 2016), «формули ввічливості» (Мацько, 2000) та ін., що спричинено їхньою сферою застосування, зокрема побутуванням у певних комунікативних ситуаціях - вітання, прощання, побажання, подяки, віншування, прохання, вибачення, поради, звертання, схвалення, люб'язності, частування, співчуття, скорботи, згоди чи відмови тощо. Систематичне уживання етикетних конструкцій, здатність відтворюватися в типових ситуаціях міжособистісного спілкування зумовило їхню усталеність у мовному фонді на певному історичному зрізі, стереотипність, трафаретність, надало характеру стійких формул, виформувавши низку семантико-функційних різновидів. До етикетних в українській лінгвістиці уналежнено різнорівневі мовні одиниці: слова, фразеологізми, словосполучення, речення (еквіваленти речень, комунікати), що відповідають національним культурним традиціям народу або окремого етносу.

Мета статті - описати змістові й функціональні параметри стереотипних культурно та етнічно зумовлених етикетних формул, уживаних у художніх текстах С. Воробкевича ${ }^{1}$, що їх буковинці уживають в типових комунікативних ситуаціях, репрезентуючи власну лінгвокультуру та картину світу.

${ }^{1}$ Ілюстративний матеріал подаємо за виданням: Твори Ізидора Воробкевича. Львів : Вид-во товариства «Просвіта»: Т. 1 : Поезії / [авт. передм. Ю. Романчук]. - 1909. - 420 с.; Т. 2 : Оповідання. - 1911. - 412 с.; Т. 3 : Драматичні твори. $-1911 .-421$ с. - (Руська письменність), зазначаючи в дужках номери тому та сторінки (цитуючи, дотримуємося правописної системи видання). 
Виклад основного матеріалу. Своєрідність і неповторність загальнонаціональної мовної картини світу увиразнюють «регіонально-діалектні картини світу, які відбивають особливості світовідчуття, світосприймання, світобачення певних етнографічних груп» (Грещук, Грещук 2018). Український мовний етикет як своєрідний вияв культурного коду нації усталився історично. Національно вкорінений, він водночас маніфестує характерні риси кожного регіону, спричинені особливостями мовного узусу та культурною специфікою. Художні тексти С. Воробкевича репрезентують мовний етикет буковинців як невіддільної частини українського етносу. Мовлення персонажів його творів сповнюють конструкції поштивого спілкування жителів Буковини, засновані на місцевих традиціях, звичаях, обрядах і віруваннях.

Найпоширеніші конструкції національно-мовного етикету функціонують, як відомо, у ситуаціях встановлення, продовження чи завершення мовленнєвого контакту. Традиційні побутові мовні формули вітання буковинців, окрім темпоральних «добрий день (вечір)», містять побажання співрозмовнику здоров'я, як-от: [Обоє:] Добрий день! [Хандиба:] Дай, Боже, здоровлєчка, синку (III, с. 129). - Добрий вечір! - оченята сльозов заросила. - Дай Господи здоровлєчко! чом так із-пізненька? (I, с. 235). До него зближив ся двацятилїтний жидок, $і$ знявии капелюх, поздоровив єго «добрим вечером». - Дай Боже здоровлєчко! - відповів він незнакомому (II с. 200). Усталеною формулою доброзичливого міжособистісного вітання буковинців виступає етикетна фразема здоров був або їі усічений варіант здоров (здорова, здорові) [був, була, були, будь, будьте і т. ін.], ускладнений звертанням, напр.: [Петро:] Здорові були! [Ілаш і Гафія:]. Здоров, Петре! (III, с. 276). [Марійка:] Здоров, Федоре! Здоров, дедю! [Оба:] Здорова була! (III, с. 68). Функцію встановлення комунікативного контакту виконують й питальні конструкції, як-от: - Чи здорові, чи миром, мої птаменята? (II, с. 30).

Вітальні мовноетикетні вирази створюють ситуативно обумовлені діалогічні єдності. Зокрема етикетна фразема боже помагай під час вітання є функціонально спрямованою, позаяк маніфестує дружню прихильність і побажання співрозмовнику успішно виконати певну роботу, напр.: - Боже помагай, панї-маточко! - Дякувать за добре слово. Куда Бог провадить, Солохівно? (II, с. 265). Такі вітальні конструкції передбачають трафаретні відповіді з семантикою подяки та зацікавлення співрозмовником.

Увічливі взаємини між комунікантами-буковинцями в художніх текстах С. Воробкевича засвідчують формули прощання переважно поба- 
жального змісту, як-от: будь (бувай, оставайся, іди) здоров (здорова, здорові): - Бувай здорова, Катерино! - Іди здоров! (II, с. 154). - Добре-добре, дїточки, бувайте здорові... (II, с. 28). Ситуацію завершення акту комунікації доповнюють формули з етикетною лексемою прощай, що зазвичай уживається в контамінації зі звертанням, пор.: [Василина:] Бувай здоров і прощзай, другої собі шукай! (III, с. 148). [Павло:] Прощайте, господарю Танасїю, бувайте зборові, пані-матко, прощуайте всі, всї! (III, с. 159). Прощальні мовноетикетні вислови експресивізує не лише семантика доброзичливого побажання здоров'я співрозмовнику, а й зичення Божого благословення, засвідчуючи побожність буковинців як рису їхнього етнохарактеру, напр.: Прощайте, отче $і$ паніматко, вашу доброту Бог нагородить! (II, с. 198). Оставайте всї здорові. Бог най буде з вами!» (I, с. 57).

Традиційний мовленнєвий етикет буковинців відображають прощальні конструкції побажального характеру, що їх висловлюють, випроводжаючи когось у далеку дорогу. Окрім традиційних виразів щасливої дороги, в добрий час фіксуємо чимало усталених мовноетикетних формул, що вияскравлюють віру буковинців у вищу небесну силу, пор.: Ще раз загуділи: Батьку-соколику, щзаслива дорога! (II, с. 28). - 3 Богом, мій сину дорогий, дай нам Господоньку в добрий час і щзасливу пору! (II, с. 153). - Провадь вас, Господи! - шепнув Гусляр (II, с. 99). - Веди тебе Пречиста Діва! - сказала стара мати (II, с. 153).

Національно специфічну систему правил мовної поведінки буковинців увиразнюють доброзичливі формули побажання. У творах C. Воробкевича фіксуємо значний пласт побажальних етикетних одиниць, уведених до художнього тексту за допомогою службових слів щзоб (щоби), нехай (най), бодай, напр.: [Гафія:]. Тетяно! Нехай тебе Бог милує! (III, с. 16). [Гнат:] Марійко, ти все така весела $i$ жартівлива! Бодай здорова була! (III, с. 77). Формули побажання співрозмовнику здоров'я, щастя, добра, гараздів, Божої помочі та благословення тощо засвідчують релігійність і непохитну віру буковинців у магію слова, як-от: - Щоб здорові були та рушники на поготові тримали, бо хороші нївроку, - заговорив я (II, с. 52). - Щоби ти здоров був і лиха не знав, дїдику Мартине! (II, с. 172). [Катерина i Гнат:] (ідуть до Федора). Нехай тобі Бог нагородить за доброту здоровлєм, довгим віком і иарством небесним і всім, кого собі лиш у Бога просиш! (III, с. 80). Етику ввічливого спілкування й побожність буковинців передають побажальні етикетні вислови з фраземами дай Боже, як-от: [1-ий стариина:] Дай Боже вам з води і з роси! (III с. 172). Дай вам, Боже, всего добра (II, с. 362). 
Етикетну культуру буковинців у досліджуваних текстах вербально репрезентують формули подяки, що містять, окрім узвичаєних етикетних маркерів спасибі, дякую, стилістично марковані відповідники спасибіг, дякувать з вказівкою на адресата мовлення, увиразненого займенниками чи звертанням, пор.: - Спасибі, Петре, що-сь мене з собою взяв (II, с. 98). [Танасій:] (до Івана). Дякую за добре слово! Спасибіг вам! (III, с. 202). [Ілаш:] Дякувать за добре слово! (III, с. 147). Зазначені етикетні сполуки можуть тлумачити зміст подяки за допомогою прийменника за, а також містити розгорнуті конструкції з семантикою взаємного доброзичливого побажання, напр.: Дякую за таку раду і пораду! - сказала нетерпеливо панї Пульхерія (II, с. 335). - Спасибіг вам, приспори вам Господи всего добра, - сказала она і наче на хвилю повеселійшала (II, с. 192). [Пентелей:] Спасибіг, паньматко, за хліб, сіль і добре слово! - Будь здорова як вода, богата як земля, щаслива як зоря, і разом двоє! (III, с. 358). Розширюють етикетні висловлення подяки наслідкові структури, що вказують на безмежну вдячність та увічливість мовця, як-от: [Данило:] Спасибіг вам, товариші! - До смерти вашої щиростн не забуду (III, с. 271). - Спасибіг, хлопче ! Колись може і я тобі відвдячу ся! - відповів сму пан Олїмпій (II, с. 332).

Стереотипні формули прохання у творах С. Воробкевича виформовують конструкції з етикетними лексемами прошу (благаю, молю), що вказують на ввічливе спонукання співрозмовника до дії, у поєднанні $з$ займенниками, звертаннями та дієслівними формами - інфінітивами чи імперативами, як-от: - Прошу вас, добрі людоньки, тілько о се одно (II, с. 219). - Прошу, не відкажіть мені $і$ заспівайте якусь пісоньку... (II, c. 355). Повтори маркерів прохання підсилюють наполегливість мовця, надаючи відтінку благання, як-от: - Панно Фльорико, прошу-благаю вас, також пїсоньку заспівати (II, с. 356). Схаменїть ся, Гуцулики, молю вас, благаю (I, c. 372).

Чимало словесних формул на позначення прохання містять усталені фраземи зі словами ласка і милість, що інтенсифікують їх увічливий характер, як-от: Коли твоя ласка, то возьми мене з собою, - сказав я тій птасї (II, с. 170). Висловлюючи прохання, буковинці поштиво просять милості та ласки, сподіваючись на милосердя співрозмовника, напр.: - Прошу, будьте ласкаві щзо заграти! (II, с. 354). Будьте милостиві і прийміть у ваш монастир одного нещасного, конаючого чоловіка! (II, с. 93). [Одарка:] Пане сендзьо! Змилуйте ся, зробіть ласку бідній дівчині (III, с. 311). Прохання буковинців, звернені до Бога, оформляють відповідні імперативи змилуйся, дай (не дай), як-от: $A x$, Боже мій милостивий, Змилуй ся Ти наді мною... (II, с. 7). Змилуй ся, 
Пречиста Діво, не дай єму марно загинути! (III, с. 208). Дай Господи, щобб їм у такім порозуміню увесь вік спливав! (II, с. 378). Інтенсифікує увічливе спонукання співрозмовника до певного вчинку в мові творів буковинського письменника фразема про милість Божу в поєднанні 3 дієсловами наказового способу, напр.: - Про милість Божу, ратуйте, добрі люди! (II, с. 326). Поможіть, ратуйте, про милість Божу! (II, с. 327). Про милість Божу, скажи єму, милий Олїмпій, нехай розуму набере! (II, с. 331).

Стереотипи ввічливості буковинців відображають і близькі до прохання формули вибачення, позначені семантикою поштивого спонукання до поблажливості. Ситуацію визнання провини вербалізують у досліджуваних текстах конструкції з імперативами прости (простіть), даруй (даруйте), вибачай (вибачайте) у контамінації з займенниками та звертаннями, напр.: - Прости, ненечко, покаяв ся блудний син $i$ знов до тебе вернув (II, с. 270). - Прости мені, Маро, прости мені, люба (II, с. 127). - Даруйте, пане, що вам не даю спокою... (II, с. 132). Люблю тебе, як мою душу, але вибачай менї, що я против тебе був таким необачним! (II, c. 382). - Вибачайте! Я забув ся (II, с. 131).

Національно-мовний етикет буковинців репрезентують формули гостинності, відображаючи одну з національних рис їхнього характеру: бажання приймати гостей, очікуваних і несподіваних, знайомих і незнайомих, як-от: Аж тут став переді мною якийсь старещь $і$ просить ся на ніч. - Та чому-ж нї, прошу до хати! - кажу я (II, с. 174). - Прошу, милий гостеньку, до покою! (II, с. 281). Усталені примовляння, зафіксовані у творах С. Воробкевича, демонструють доброзичливість господарів та миролюбність до того, хто завітав до їхньої хати, пор.: - Мої двері отворені кождому чесному чоловікови, - сказав Хома (II, с. 45). - Сїдай, старий - просив Петро гусляря, - сідай і спочинь; $і$ для тебе знайдеть ся куточок, дїлити-мем хлїб-сіль, як ділимо одну лукаву долю... (II, с. 98). Експресивізують художній текст римовані припрошування, як-от: $\mathrm{He}$ дурно сорока скреготала, она нам гостий казала... (II, с. 51); [Санда:] Просимо до хати! Нама хата на помості - просим, просим, милі гості!! (III, с. 353). - Здоров, Пастеровичу Миловане, отсе сьвятило ся - через долинку та в гостинку (II, с. 69).

Елементи світогляду, вірувань й повір'їв буковинців оприявнюють прохання гостеві не лише переступити поріг, а й сісти за стіл, а надто в тій хаті, де проживали ще не засватані дівчата, напр.: - Сїдайте, мої гостї, щоб усе добре сїдало! - припрошує нас Хома, а я додав сьміючи ся: «щоб і старости сїдали» (II, с. 51-52); - Просимо сїдати, щоб рої сідали! - мовила привітливо вдова Маріора (II, с. 349). [Санда:] Розгост- 
їть ся, сідайте! [Тетяна:] Щоб старости і квочки сідали! (III, с. 348). Традиція гостинності передбачає пригощання й частування гостя, що вербалізують такі етикетні конструкції: Прошу, розгости ся! - молила у дверях стоячого Олїмпія панї Пульхерія (II, с. 327). - Прошу до комнати, розгостїть ся, розігрійте ся і розповіджте, як вам поводило ся? (II, с. 365). Прошу, мої гостї; чим хата має, тим і приймає (II, с. 57).

3-поміж мовноеткетних висловів, закріплених національно-культурними і мовними традиціями, вирізняються формули утішання, що ними буковинці оперують, бажаючи заспокоїти співрозмовника, допомоги позбутися суму, неспокою, хвилювання тощо, як-от: - Не журися! Якось то буде. Слухай лиш моєї ради, банувати не будеш! (II, с. 364). - Не смутіть ся, паничу Аврельцюю! Ще сьвіт не запав ся, - шепнула доматорка ласкавим, потішаючим голосом, додаючи мені тим відваги (II, с. 282). Такі етикетні формули засвідчують співчутливість, щиросердність, чуйність буковинців, уміння розділити чужий біль, підтримати у важку хвилину, пор.: Твоє щастє моӥм щастєм, твій біль мойм болем (II, с. 153). - Кажи, дорогий Леонїде; твій біль мойм болем, легше єго у двох зносити! - відповіла Фльорика (II, с. 382).

Мовні стереотипи комунікативного акту втішання виявляють доброзичливе, прихильне ставлення до співрозмовника, намагання підбадьорити й розрадити в горі, пор.: - Не жури ся, сизокрила. Господь Бог того не допустить - рекла бідна Ірина, потішаючи стару Єлу (II, с. 114). - Не плач, не розбивай ся, моя рідна! Плачем крайної нужди не позбути ся... (II, с. 324). Окрім дієслівних імперативів не плач, не журись, не розбивайся, не смутися, не бійся формули утішання в текстах С. Воробкевича містять усталені фразеологізовані конструкції, оприявнюючи паремійну творчість буковинців, як-от: - Не бійсь, хлопче; біла риза не веде до пекла, але прямісенько до сьвітлого раю (II, с. 331). - Не плач, зазуленько, плачем лиха не виплачеш, - потішала стару Ірина. - Вже нам так суджено до гробової дошки терпіти! (II, с. 114). [Танасїй] Не журись, Тетяно; нещастє не таке велике, як собі думаєщ. Бог батько! Щоби-м землю нігтями скородив, то біди вже більше не зазнаєи (III, с. 201). Такі стереотипні побудови узагальнюють мовний досвід жителів Буковини, глибокозмістовно та сконденсовано відтворюючи їхню розумово-мовленнєву креативність.

Висновки та перспективи подальшого дослідження. Етикетні висловлення відображають морально-етичні норми, що регулюють мовленнєву поведінку носіїв певної лінгвокультурної спільноти. Репертуар стереотипних стійких формул спілкування, зафіксованих у художніх текстах С. Воробкевича, розмаїта і віддзеркалює особливості менталі- 
тету буковинців - головних героїв творів видатного письменника Буковини. Репрезентуючи споконвічні народні традиції та християнські принципи, різнотипні усталені словесні конструкції мають переважно побажальний характер та релігійний зміст, актуалізують традиційні локальні мовні ресурси, демонструють паремійну творчість буковинців. Випрацювані віками та закріплені в побуті узвичаєні та стилістично марковані (розмовні, діалектні) мовні етикетні формули привітання, прощання, побажання, подяки, прохання, вибачення, гостинності, утішання тощо відбивають віру буковинців у магічну силу слова та увиразнюють такі їхні етнопсихологічні риси, як доброзичливість, увічливість, чуйність, щиросердність, шанобливість, побожність, релігійність, емоційність тощо.

Перспективним видається подальший аналіз текстів С. Воробкевича щодо функціонування мовноетикетних одиниць, релевантних для комунікативних ситуацій віншування, сватання, благословення, схвалення, поради, люб'язності, згоди чи відмови тощо, як ідентифікаторів ментального світосприйняття жителів Буковини.

\section{СПИСОК ЛІТЕРАТУРИ}

Богдан, С. К. (1998). Мовний етикет украӥниів: традииї̈ і сучасність. Київ: Рідна мова.

Гуйванюк, Н. В. (1995). Етнопсихологічні особливості етикетних висловлень буковинців у XIX ст. Матеріали III Міжнародної історико-краєзнавчої наук. конференції, присвяченої 120-річчю заснування Чернівецького університеmу. Чернівці: Рута, $112-115$.

Грещук, В, \& Грещук, В, (2018). Мовна картина світу гуцулів крізь призму художньої мови. Полонина. Рідне слово в етнокультурному вимірі: зб. наук. праць. Дрогобич: Посвіт, DOI: hppt:/dx.doi.org/10.24919/2411-4758.2018.140897

Єрмоленко, С. Я. (2004). Мовний етикет. Украйнська мова, 2-ге вид., $362-$ 363.

Мацько, О. (2000). Формули ввічливості в дипломатичному листуванні. Дивослово, № 2, 14-17.

Миронюк, О. М. (1993). Історія украӥнського мовного етикету (засоби вираження ввічливості). (Автореферат дис. канд. філол. наук). Київ, 22 с.

Плющ, Н. П. (1991). Формули ввічливості в системі українського мовного етикету. Украӥнська мова і сучасність. Київ: НМК ВО, 90 - 98.

Прилипко, Ф. (2016). Етикетні комунікеми в сучасній українськомовній мультиплікації. Українська мова, 4, 136 - 143.

Радевич-Виницький, Я. (2008). Етикет і культура спілкування. Львів: СПОлОМ.

Стахів, М. (2008). Украӥнський комунікативний етикет. Київ: Знання.

Стельмахович, М.Г. (2001) Український мовленнсвий етикет. Урок украйнської, № 3, $14-15$. 


\section{REFERENCES}

Bohdan, S. K. (1998). Movnyi etyket ukraintsiv: tradytsii i suchasnist [Language etiquette of Ukrainians: traditions and modernity]. Kyiv, Ridna mova. [in Ukrainian]

Huivaniuk, N. V. (1995). Etnopsykholohichni osoblyvosti etyketnykh vyslovlen bukovyntsiv u XIX st. [Ethnopsychological features of etiquette statements of Bukovynians in the XIX century.]. Materialy III Mizhnarodnoi istoryko-kraieznavchoi nauk. konferentsii, prysviachenoi 120-richchiu zasnuvannia Chernivetskoho universytetu - Proceedings of the III International Historical and Local History Scientific Conference dedicated to the 120th anniversary of the Chernivtsi University. Chernivtsi, Ruta, 112 - 115. [in Ukrainian]

Greshchuk, V, \& Greshchuk, V. (2018). Movna kartyna svitu hutsuliv kriz pryzmu khudozhnoi movy. Polonyna [Linguistic picture of the Hutsul world through the prism of artistic language. Polonina]. Ridne slovo v etnokulturnomu vymiri: zb. nauk. prats - Native word in the ethnocultural dimension: Coll. Sciense. DOI: hppt://dx.doi. org/10.24919/2411-4758.2018.140897 [in Ukrainian]

Yermolenko, S. Ia. (2004). Movnyi etyket [Language etiquette]. V entsyklopedii Ukrainska mova - Ukrainian language: encyclopedia (2-he vyd., 362-363). [in Ukrainian]

Matsko, O. (2000). Formuly vvichlyvosti v dyplomatychnomu lystuvanni [Formulae of politeness in diplomatic correspondence]. Dyvoslovo - Wonder word, 2, 14-17. [in Ukrainian]

Myroniuk, O. M. (1993). Istoriia ukrainskoho movnoho etyketu (zasoby vyrazhennia vvichlyvosti) [History of the Ukrainian language etiquette (means of politeness expression)]. (Extended abstract of candidate's thesis). Kyiv. [in Ukrainian]

Pliushch, N. P. (1991). Formuly vvichlyvosti v systemi ukrainskoho movnoho etyketu [Politeness formulae in the system of the Ukrainian language etiquette]. Ukrainska mova i suchasnist - Ukrainian language and modernity. Kyiv, NMK VO, 90 - 98. [in Ukrainian]

Prylypko, F. (2016). Etyketni komunikemy v suchasnii ukrainskomovnii multyplikatsii [Etiquette communiquems in modern Ukrainian-language animation]. Ukrainska mova - Ukrainian language, 4, 136 - 143. [in Ukrainian]

Radevych-Vynytskyi, Ya. (2008). Etyket i kultura spilkuvannia [Etiquette and the culture of communication]. Lviv: SPOLOM. [in Ukrainian]

Stakhiv, M. (2008). Ukrainskyi komunikatyvnyi etyket [Ukrainian communicative etiquette]. Kyiv, Znannia. [in Ukrainian]

Stelmakhovych, M. H. (2001). Ukrainskyi movlennievyi etyket [Ukrainian speech etiquette]. Urok ukrainskoi - Ukrainian lesson, 3, 14 - 15. [in Ukrainian] 